2014

\title{
What is Environmental Justice?
}

Dayna Nadine Scott

Osgoode Hall Law School of York University, dscott@osgoode.yorku.ca

Follow this and additional works at: http://digitalcommons.osgoode.yorku.ca/olsrps

\section{Recommended Citation}

Scott, Dayna Nadine, "What is Environmental Justice?" (2014). Osgoode Legal Studies Research Paper Series. 4. http://digitalcommons.osgoode.yorku.ca/olsrps/4 


\title{
OSGOODE HALL LAW SCHOOL LEGAL STUDIES RESEARCH PAPER SERIES
}

\section{Research Paper No. 72}

Vol. 10/ Issue. 16/ (2014)

\section{What is Environmental Justice?}

Scott, D. (2014). Environmental justice. In M. Brydon-Miller \& D. Coghlan (Eds.) The SAGE encyclopedia of action research. forthcoming.

\section{Dayna Nadine Scott}

\section{Editors:}

Editor-in-Chief: Carys J. Craig (Associate Dean of Research \& Institutional Relations and Associate Professor, Osgoode Hall Law School, York University, Toronto)

Production Editor: James Singh (Osgoode Hall Law School, York University, Toronto)

\author{
This paper can be downloaded free of charge from: \\ http://ssrn.com/abstract=2513834
}


Osgoode Legal Studies Research Paper No. 72

Vol. 10/ Issue. 16/ (2014)

\title{
What is Environmental Justice?
}

Scott, D. (2014). Environmental justice. In M. Brydon-Miller \& D. Coghlan (Eds.) The SAGE encyclopedia of action research. forthcoming.

Dayna Nadine Scott

\begin{abstract}
:
This posting outlines the concept of "environmental justice" as I recently described it for an encyclopedia entry in the field of "Action Research". In this discipline, the term "environmental justice" describes more than a fair outcome. It is a social movement, and a theoretical lens, that is focused on fairness in the distribution of environmental benefits and burdens, and in the processes that determine those distributions. In both cases, an attention to environmental justice means amplifying the voices of poor, racialized and Indigenous communities in environmental and natural resource policy-making venues -places that have typically produced decisions resulting in those communities bearing more than their "fair share" of environmental harms. It also means, increasingly, paying attention to the manner through which disadvantaged and historically oppressed peoples within those communities will often be disproportionately harmed, often along familiar social gradients of gender, class, sexuality, caste, and (dis)ability. Effective research in the environmental justice framework has tended to involve robust partnerships between local communities, organizations and/or groups of activists seeking to achieve environmental justice, and university-based researchers employing participatory-action methodologies. These collaborative efforts have proven to be very fruitful in many cases, but should not be understood as easy or straightforward to implement. New models are emerging that seek to combine and enhance the expertise, capacities and perspectives of the partners in order to meet primarily, the needs of communities, and secondarily, the aims of researchers.
\end{abstract}

\section{Keywords:}

Environmental Justice; Action Research; Public Participation; Environmental harms

\author{
Author(s): \\ Dayna Nadine Scott \\ Associate Professor \\ Osgoode Hall Law School \\ York University, Toronto \\ E: dscott@osgoode.yorku.ca
}


Dayna Nadine Scott, Entry for "Environmental Justice" in The SAGE Encyclopedia of Action

Research, edited by David Coghlan and Mary Brydon-Miller (2014).

\section{ENVIRONMENTAL JUSTICE}

Environmental justice is a social movement, and a theoretical lens, that is focussed on fairness in the distribution of environmental benefits and burdens, and in the processes that determine those distributions. That is, it is concerned with both the 'fair treatment' and the 'significant involvement' of poor, racialized and indigenous communities in environmental policy and natural resource development decisions that have typically resulted in those communities bearing more than their "fair share" of environmental harms. Jonathan London and Julie Sze have conceptualized environmental justice as praxis, noting that it draws from and integrates theory and practice into a mutually informing dialogue. Framing environmental justice in this way provides the flexibility needed to allow it to encompass the wide variety of dynamics that are brought forward by many different populations, problems and places.

\section{Theoretical Lens}

Academic research employing an environmental justice lens tends to be interdisciplinary, participatory and concentrated in the social sciences. It is concerned with systemic issues of power and ownership in relation to nature, capital and labour that produce disparities in access to environmental benefits such as parks, gardens, bike paths or farmer's markets, and in the distribution of environmental burdens, such as air and water pollution, contaminated soils, and toxics in the workplace. Scholars working in this area tend to cast a broad net to allow consideration of how exploitative relationships between industrial actors and marginalized 
communities, including workers, transcend into peoples' everyday lives. These scholar-activists are typically interested in breaking down disciplinary boundaries that may exist between research on health, work, and environmental issues. At its most basic, employing an environmental justice lens means that we take account of the sharing of costs and benefits associated with environmental policy and natural resource development decisions, and the extent to which the decision-making has meaningfully included the participation of affected communities.

\section{Social Movement: "We Speak for Ourselves"}

The environmental justice movement distinguishes itself from the mainstream environmental movement by making grassroots political organizing its central priority. Where environmentalists over the past three decades have invested heavily in legal strategies as a means to achieve social change, the environmental justice movement, in contrast, explicitly calls this focus on law reform into question by noting how it continues to privilege elites at the expense of people working on the ground to improve their communities. Similarly, the environmental justice movement has focused on the health and wellbeing of people, rather than on the need to protect "the environment" conceptualized as wilderness spaces, endangered species or national parks, with the latter sometimes dismissed as 'playgrounds for the rich'. Thus, activists in the environmental justice movement are increasingly turning their attention to environmental harms derived not only from air, water or soil contamination, but from toxic workplaces, urban planning and transit decisions, conditions in public housing projects (such as lead paint or mould), water and sanitation services on native reserves, urban "food deserts" etc. Their work highlights the relationships between profit incentives, the unsustainable production of waste, exploitative labour practices, and differential exposure to pollutants. At the same time, 
environmental justice activism and scholarship emanating from within indigenous communities tends to emphasize the interconnectedness of people and their environments, and the narrowness and short-sightedness of the approach that would separate the well-being of ecosystems from those who depend on them.

\section{Origins}

The environmental justice movement is often considered to have emerged in the U.S. in the late 1980s as poor communities of color organized to fight the disproportionate siting of hazardous waste facilities in their neighborhoods. In this context, an "environmental justice community" came to be understood as a racialized population of a lower socioeconomic level surrounded by or affected by dirty industry, typically petroleum refineries or coal-fired utilities, chemical plants, municipal landfills, nuclear plants, or hazardous waste dumps. It is commonly said that these are the communities that need the most, in terms of resources and policy attention, but receive the least. The United States Environmental Protection Agency defines Environmental Justice as "the fair treatment and meaningful involvement of all people regardless of race, color, sex, national origin, or income with respect to the development, implementation and enforcement of environmental laws, regulations, and policies."

The origins of the environmental justice movement in the US are sometimes traced to Love Canal, where a low-income community of mostly white residents plagued by birth defects, cancers and respiratory problems in upstate New York in the 1970s was led by a determined group of self-identified "house-wives" to both trace the path of the contamination (to a toxic underground 'plume` from leaking drums of chemical waste left behind by Hooker Chemicals) 
and to eventually win compensation and re-location for residents. The state agency`s meagre initial attempts to buy-out homes in the area became a notorious example of the devaluing of low income people's health, and it cemented the inclusion of America's poor in conceptions of environmental justice. Lois Gibbs, who led the struggle and went on to found a national environmental justice organization, would later say that the "media and general public.... have finally got it... [the environmental justice movement ]... is about people and the places they live, work and play".

The centrality of race to the US movement was established by the iconic uprising in Warren County, NC that played out in the early 1980s. When Warren County, a predominantly African-American community, was chosen as the state's dumping ground for truckloads of soil laced with PCBs, the people of Warren County unexpectedly rallied. The struggle, although ultimately unsuccessful, drew national attention to the issue and stimulated a rash of empirical studies that would later provide support for the phenomenon of environmental racism. The most important of these studies was undoubtedly the 1987 report by the United Church of Christ Commission for Racial Justice which defined environmental racism as the "intentionally selecting communities of color for waste disposal sites and polluting industrial facilities", and demonstrated that race, and not household income or home prices, was in fact the best predictor of the location of hazardous waste facilities in the U.S.

If the environmental justice movement was conceptualized in the 1970s and 80s, it had been building for a long time, like a river "fed by many tributaries" in Cole \& Foster's words. Important influences included the American civil rights movement, the struggles of migrant 
farmworkers led by Cesar Chavez in California the 1960s, and the struggles against uranium

mining by Native Americans. In Canada, indigenous people fought in the 1960s and 70s against the pulp-and-paper industries that were sickening them through mercury-poisoned water, the aluminium and auto manufacturing industries that fouled their territories and their bodies, and the long-range transport of industrial pollutants that penetrated even mother`s milk. The movement has gathered strength over the past three decades as residents of affected communities and their allies have come to realize that the disproportionate impact of environmental hazards today can be traced to the same social and economic structures which have produced slavery, colonization, segregation and other forms of systemic oppression. These connections were articulated at the First National People of Colour Summit in 1991 in Washington, D.C., which produced seventeen principles of environmental justice drafted by hundreds of grassroots and national leaders from the Americas and beyond. Sociologist Robert Bullard, co-founder of the Summit and one of the first to sound the alarm on "environmental racism", called the conference the most important single event in the movement's history.

\section{Tensions and Questions in Contemporary Environmental Justice Research}

It is now well-documented that racialized and marginalized communities, including and perhaps especially indigenous communities, in many parts of the world bear much more than their 'fair share' of environmental burdens; it is also becoming increasingly clear that disadvantaged and historically oppressed peoples within those communities will often be disproportionately harmed, often along familiar social gradients of gender, class, sexuality, caste, (dis)ability etc. With respect to gender, it is worth noting that at the second People of Colour Environmental Leadership Summit in 2002, Peggy Shepard of West Harlem Environmental 
Action argued that women on-the-ground are driving this movement, despite the fact that they remain underrepresented in leadership roles. And as Barbara Rahder has demonstrated, there are structural and spatial inequities in production and reproduction inherent to the neoliberal political economy that serve to perpetuate this reality. Deficiencies in childcare and eldercare regimes, and the persistently uneven and gendered division of domestic work, exacerbate the problem. Debates persist over whether the central role of women in this movement is an expression of an inherent ethic or politics of care, or, as Sherilyn MacGregor has put forward, a form of politicized ecological citizenship.

As environmental justice activists began to encounter success in their battles against the siting of industrial facilities and hazardous waste sites, the charge of "NIMBY-ism" (Not-in my-backyard syndrome) began to plague the movement. It became clear that successful grassroots struggles in the US, Canada and other nations of the global North, led by women, could be displacing heavy industrial facilities and hazardous waste disposal sites in a way that would intensify the burdens facing people of the global South. The rallying cry "Not in anyone`s backyard“ was the movement`s answer. The anti-toxics movement, the climate justice movement, and the resistance to Tar Sands pipelines that is currently building across North America, all serve as important examples of how movement activists and scholars have put forward solutions that seek to address the root causes of problems, rather than simply pass the impacts of business-as-usual industrial development on to the next most vulnerable community.

The notion of climate justice illustrates the North-South dynamic: it is indisputable that the most marginalized peoples and impoverished countries of the world are the least responsible 
for greenhouse gas emissions, and yet, will and do bear the biggest brunt of the burden of climate impacts. Juan Martinez-Alier`s phrase “effluents of affluence”, describes the way that overconsumption in the North fuels much of the problem in both the North and the South. The notion that the "environmentalism of the poor" is a new phenomenon, however, is highly contested. While activists in the anti-toxics movement sometimes posit that a whole new brand of environmentalists are emerging, and that this group is composed of youth and women from working class, immigrant and racialized communities for whom the environment is not an abstract ideal, but an immediate, concrete reality, others counter that these grassroots, participatory, and community-based organizations build on a rich history of history of resistance. Environmental historians have challenged the once-popular notion that racialized and immigrant populations are "too busy surviving" to care about the environment. In fact, it has been argued that it was instead a question of re-definition: once the "environment" was conceptualized to include housing, transit, work and pollution concerns, it became obvious that poor and marginalized people have been "environmentalists" all along. Other scholars do acknowledge the real barriers that being "busy surviving" creates, and also highlight the lack of meaningful opportunities to participate for many disenfranchised local residents, and the way that prevailing benchmarks for demonstrating credibility and authority are highly skewed towards the expert knowledges of elites.

Important questions around representation and agency inherent in the idea of "speaking for ourselves" persist as difficult ones to resolve for movement activists and environmental justice scholars. It seems clear that, as Guha has argued, what is "new" about the environmental justice movement is not the "elevated environmental consciousness" of its members but the ways 
that it is transforming the possibilities for fundamental social and environmental change through collective action, and the forging of new forms of grassroots political organization. A key element in the process through which local residents transition from victims to agents of change - participants in the decisions that affect their everyday lives - is the realization by ordinary people that the power relationships within a given policy setting or decision-making structure are fluid and contestable, and that they can be shifted. Environmental justice struggles thus often become battles over data and expertise, as local residents engaged in popular epidemiology come to recognize the way that power and authority is gained and held. It is a movement fundamentally engaged in a transformative politics.

\section{Environmental Justice and Action Research}

Effective research in the environmental justice framework has tended to involve robust partnerships between local communities, organizations and/or groups of activists seeking to achieve environmental justice, and university-based researchers employing participatory-action methodologies. These collaborative efforts have proven to be very fruitful in many cases, but should not be understood as easy or straightforward to implement. New models are emerging that seek to combine and enhance the expertise, capacities and perspectives of the partners in order to meet primarily, the needs of communities, and secondarily, the aims of researchers. Creative scholarship exploring practical strategies and tools for successfully building and managing these collaborations is demonstrating how such partnerships can strengthen and enrich research outcomes, and how participatory action research can advance the goals of community activists in the best of cases. 
Principles of collaboration that are emerging include attention to the preservation of voice and decision-making authority for the community, arrangements in which the ownership and control of data generated by the research is maintained by the community, as well as authority to share it. Effective collaborations also often include an explicit commitment from researchers that they will try to increase the capacity of existing community groups and individuals over the course of the partnerships (leaving the organization in 'better shape than they found it'), and that they will appropriately compensate individuals and organizations that contribute to the work for their expertise, time and intellectual work.

See also: Environmental Racism; Reproductive Justice; Environmental Equity

\section{Further Readings}

Agyeman, Julian et al, eds. Speaking for ourselves: Environmental justice in Canada (Vancouver: UBC Press, 2009).

Austin, Regina \& Michael Schill. "Black, Brown, Red and Poisoned," in Unequal Protection: Environmental Justice and Communities of Color, Robert Bullard, ed (San Francisco: Sierra Club Books, 1994) 54.

Bullard, Robert D. Dumping in Dixie: Race, Class, and Environmental Quality (Boulder: Westview Press, 1990).

Cole, Luke W \& Sheila R Foster. From the Ground Up: Environmental Racism and the Rise of the Environmental Justice Movement (New York: New York University Press, 2001).

Di Chiro, Giovanna. "Local Actions, Global Visions: Remaking Environmental Expertise" (1997) 18:2 Frontiers 203.

Gosine, Andil \& Cheryl Teelucksingh. Environmental Justice and Racism in Canada: An Introduction (Toronto: Emond Montgomery, 2008).

Guha, Ramachandra. Environmentalism: A Global History (New York: Longman, 2000). 
Lerner, Stephen D. Sacrifice Zones: The Front Lines of Toxic Chemical Exposure in the United States (Cambridge: MIT Press, 2010).

MacGregor, Sherilyn. Beyond Mothering earth: Ecological Citizenship and the Politics of Care (Vancouver: UBC Press, 2006).

Martínez-Alier, Juan. "From Political Economy to Political Ecology" in Ramachandra Guha and Juan Martínez-Alier, Varieties of Environmentalism: Essays North and South. (New York: Earthscan, 1997) 22.

Scott, Dayna Nadine. "Confronting Chronic Pollution: A Socio-Legal Analysis of Risk and Precaution" (2008) 46:2 Osgoode Hall Law Journal 293.

Sze, Julie \& Jonathan K London. "Environmental Justice at the Crossroads" (2008) 2:4 Sociology Compass 1331.

United Church of Christ, Toxic Wastes and Race in the United States: A National report on the Racial and Socio-Economic Characteristics of Communities with Hazardous Waste Sites (New York: United Church of Christ, 1987). 